in the future become, in varying degrees, potential sources of instability in the world's oil trade, but in this connexion it would seem that the growing importance of an ever-increasing Russian production has not been assessed at its true significance. Further, Mr. Garfias's figures do not consider estimates of potential oil reserves but cover only the world's oil supplies estimated to remain underground in the present-known producing fields and their anticipated extensions.

\section{Electric Trolley Omnibuses}

Aвout twenty years ago, electric tramways had no serious rivals for street passenger traffic. As they are doing to-day, they were then carrying a very large number of passengers. The advent of petrol and electric omnibuses was not considered as a serious menace to their prosperity. They would doubtless be useful in those districts where the cost of installing tramway track was prohibitive. In a paper read to a joint meeting of the Institution of Electrical Engineers and the Institute of Transport on April 10, C. J. Spencer described the progress made in developing electric trolley omnibuses during the last twenty years and discusses the general problem of street passenger traffic. The great advantage of a trolley omnibus is that it can use a series electric motorthe most perfect of all traction motors. It gives its maximum torque when starting and can carry an overload of a hundred per cent for several minutes without damage.

THE War hindered the development of the trolley bus. Ten years ago, only 47 route miles were operated in Great Britain. Last year the number had increased to 256 miles and numerous extensions are being planned. The modern electric bus is little more than an adapted petrol bus; the engine and gear box have been removed, an electric motor substituted and a trolley collecting gear bolted on the roof. The weight of the motor used for trolley bus operation is only $12 \mathrm{lb}$. per horse power. This compares with $70 \mathrm{lb}$. per horse power in pre-War days. In the early buses, two motors of 20 h.p. were used in each bus but now a single 80 h.p. motor is used. This is capable of withstanding the roughest usage. The London United Tramways Co. recently converted 17 miles of route between Twickenham and Wimbledon into trolley bus operation. At the start, many complaints were made by possessors of radio sets of extraneous noises in their apparatus due to 'interference' by the buses. Thanks to the help of the (xeneral Post Office and the British Broadcasting Corporation this trouble has been practically overcome. On busy routes, evolution of design has led to a continual increase in the size of the vehicles.

\section{National Research Council of Canada}

TwE fifteenth annual report of the National Research Council of Canada (Ottawa) surveys the activities of the Council in the period 1931-32. The demand for scientific assistance from industrial groups was greatly increased and, during the year, the
Council considerably extended its direct relations with industry, a number of associate committees having been formed as a result of the Council's effort to relate itself with industrial development. The Council is largely echoing the views of the Advisory Council for Scientific and Industrial Research in Great Britain in asserting, and demonstrating from its own experience, that science will not occupy its proper place until the industrialist is ready, not merely to admit the possibilities of research and accept its assistance, but also to co-operate fully and on a confidential basis with workers in the scientific field. The report summarises the activities of the laboratory divisions as well as the activities of associated committees and the reports of assisted researches. From this wealth of information it is impossible to select more than a few points illustrating the scope of the investigations covered. Both in the Division of Chemistry and in that of Biology and Agriculture, considerable attention has been devoted to chemicals and herbicides as well as to the fire hazards attached to their use. Synthetic rubber and resins and the efficiency of detergents are other questions investigated by the Division of Chemistry, while the Division of Physics and Engineering has been concerned with aeronautics, locomotive research, and fire hazards of oil burners. Associate eommittees have dealt with a wide range of problems of animal diseases, field crop diseases, coal classification and analysis, engineering standards, gas research, grain research, leather, magnesian productis, oceanography, radio research, tuberculosis, weed control, and wool.

\section{Agricultural Societies}

The gain to agriculture from the activities of the various agricultural societies which have flourished during the last two centuries must be enormous. These associations, supported by landlord enthusiasts bent on improving their estates and raising the standard of farming, have spread agricultural knowledge by their publications, by the offer of prizes for information or practical achievement, and by their shows of implements and live-stock. They have continually fostered scientific inquiry into the technical problems of farming, and in their journals are to be found the successive landmarks of agricultural progress. On June 8, 1723, was founded the earliest association of this kind in Scotland under the title "The Honourable the Society of Improvers in the Knowledge of Agriculture in Scotland". Its members were certain noblemen and gentlemen who were impressed by the backward state of farming at this period. The Society was concerned with the collection and dissemination of the best agricultural information. It advised mernbers on their farming problems ; on cultivations, including the new horsehoeing huskandry of Jethro Tull, on sheep folding and on cattle feeding. Under the last heading the recommendation that the cattle be "not less than seven years old" before feeding commences, reads rather strangely in these days of 'baby beef' and rapid turnover. On the other hand, few stockmen will find fault with this:- "Be sure 